\title{
ANALISIS KOMODITAS UNGGULAN SUB SEKTOR PERKEBUNAN DI KABUPATEN BENGKAYANG PROVINSI KALIMANTAN BARAT
}

\author{
RAKHMAD HIDAYAT \\ Staf Pengajar Jurusan Sosial Ekonomi Pertanian Fakultas Pertanian \\ Universitas Tanjungpura
}

\begin{abstract}
The aims of this research was: (1) to find out the leading commodities in plantation sub sector in Bengkayang District Area, (2) to find out the structure and the production growth of plantation commodities in Bengkayang District Area (2005-2012). Research area was determined purposively in Bengkayang District Area of West Kalimantan. Analysis used in this research is the analysis of Location Quotient (LQ), Dynamic Location Quotient (DLQ), Classic Shift Share and Esteban Marquillas Shift Share.

LQ analysis show that the leading plantation commodities in Bengkayang are Peppers, Cacao, cloves and hazelnut. DLQ analysis show that the leading plantation commodities in Bengkayang are coconut and hybrid coconut. The combined of LQ and DLQ analysis show that there are two commodities experiencing repositioning of non leading became the leading commodity in the future, ie Hybrid Coconut and Coconut. The commodities that experienced a repositioning of leading became the non leading in the future are Rubber, Pepper, Cocoa, Clove and hazelnut. While commodities that stil remain non leading in the future is oil palm, coffee and Pinang.

Based on the classic shift share analysis, shows that in the period 2005 - 2012, commodities that experienced an increase in real growth in Bengkayang are Rubber, Oil Palm, Cocoa, Clove, hazelnut and Pinang. The highest increase in productivity occurred in Palm Oil and Rubber.

Esteban - Marquillas shift share analysis shown that the commodities that have a competitive advantage is oil palm, hybrid coconut, cocoa, cloves and hazelnut. Palm oil has the highest competitive advantage in the amount of $8.565,97$ tons. Plantation commodities which has the advantage and can improve the allocation of production growth in the plantation crop are Bengkayang Coffee, Cocoa, Clove, Pecan and Pinang. Cocoa has the highest allocation advantages in increasing farm production in Bengkayang. Cocoa is also a commodity that has a competitive advantage and excellence allocation with the highest positive value.
\end{abstract}

Keywords: Plantation commodities, Leading Commodities, Location Quotient, Shift Share

\section{PENDAHULUAN}

\section{Latar Belakang}

Perkebunan sebagai bagian integral dari sektor pertanian merupakan sub sektor yang mempunyai peranan penting dan strategis dalam pembangunan nasional. Peranannya terlihat nyata dalam penerimaan devisa negara melalui ekspor, penyediaan lapangan kerja, pemenuhan kebutuhan konsumsi dalam negeri, bahan baku berbagai industri dalam negeri, perolehan nilai tambah dan daya saing serta optimalisasi pengelolaan sumberdaya alam secara berkelanjutan. Peranan sub sektor perkebunan bagi perekonomian nasional tercermin dari nilai PDB perkebunan secara kumulatif mengalami peningkatan pada 20052010 tumbuh rata-rata per tahun sebesar 19,3\%. Berdasarkan harga konstan tahun 2000, nilai PDB perkebunan secara kumulatif juga mengalami peningkatan pada 2005-2010 dengan rata-rata laju pertumbuhan per tahun mencapai 3,6 \%. (Anonim, 2011)

Titik berat pembangunan bidang pertanian perlahan mulai bergeser dari pertanian 
tanaman pangan ke tanaman perkebunan unggulan yang mendukung agroindustri, seperti kelapa sawit dan karet. Dimana agroindustri komoditas perkebunan ini merupakan sarana meningkatkan nilai tambah, membuka lapangan kerja, memperluas pasar bagi produk pertanian dan menunjang usaha peningkatan pendapatan serta kesejahteraan petani. Karakteristik agroindustri ini, arah strategi pengembangannya harus didasarkan pada pendekatan wilayah potensi sumberdaya dengan tetap berpijak pada konsep keunggulan komparatif (Syam dan Ma'arif, 2004). Oleh sebab itu, sentuhan kebijakan bagi pengembangan pembangunan pertanian wilayah khususnya sektor perkebunan, masih sangat diperlukan untuk meningkatkan kesejahteraan masyarakat petani (Witjaksono dkk, 2005).

Di Kabupaten Bengkayang Provinsi Kalimantan Barat sub sektor perkebunan mempunyai peranan penting dalam perekonomian. Peranan sub sektor ini dapat dilihat dari kontribusinya pada PDRB Kabupaten Bengkayang yaitu sebesar 309.136.68 juta rupiah dari total PDRB Kabupaten Bengkayang pada tahun sebesar 1.166.187.32 juta rupiah (28 $\%$ ) pada tahun 2010. Kontribusi tersebut tertinggi kedua setelah sub sektor tanaman pangan yaitu 661.578.09 juta rupiah (48\%) (BPS Kalbar, 2011).

Berdasarkan data tahun 2012 di Kabupaten Bengkayang terdapat lahan potensial untuk tanaman perkebunan seluas 116,196 hektar. Namun luas areal perkebunan yang ada saat ini yang baru menghasilkan mencapai 54,386 ha $(42,5 \%)$ yang merupakan perkebunan rakyat yang terdiri dari kelapa sawit 52.773 ha, karet 32,662 ha, kakao, lada 9 ha, dan kopi 307 ha (Dinas Perkebunan Propinsi Kalimantan Barat, 2012). Berdasarkan luas lahan potensial untuk tanaman perkebunan yang dimiliki masih terbuka peluang pengembangan komoditas perkebunan di Kabupaten Bengkayang.

Komoditas perkebunan tersebut banyak diusahakan oleh petani lokal yang tersebar di tujuh belas kecamatan di kabupaten Bengkayang. Komoditas yang dominan diusahakan antara lain kelapa sawit, karet, kopi dan lada. Komoditas sawit dan karet mengalami kecendrungan peningkatan setiap tahunnya, hal tersebut mengindikasikan bahwa komoditas tersebut semakin diminati untuk diusahakan oleh petani.

Perkembangan produksi tanaman perkebunan di Kabupaten Bengkayang untuk semua komoditas cenderung meningkat setiap tahunnya.. Peningkatan luas areal dan produksi tanaman perkebunan di Kabupaten Bengkayang dinilai masih kurang dalam menciptakan kesempatan kerja yang lebih banyak disebabkan produksi tanaman perkebunan masih belum optimal dan peran sektor agroindustri masih kurang dirasakan oleh masyarakat. Dimana Peran sektor agroindustri tersebut antara lain dapat meningkatkan nilai tambah, penyerapan tenaga kerja dan pendapatan rumah tangga (Sinaga dan Susilowati, 2007).

Pengembangan agroindustri perkebunan seharusnya mengacu pada pendekatan komoditas unggulan. Sampai saat ini belum ada suatu acuan yang akurat bagi Pemerintah Kabupaten Bengkayang untuk menentukan kebijakan industri yang sesuai dengan komoditi perkebunan unggulan yang memberikan nilai tambah memadai dan memberikan kontribusi yang tinggi bagi pertumbuhan ekonomi daerah. Diversifikasi produksi belum berkembang dan hasil ikutannya belum dimanfaatkan. Hal ini dikarenakan tingkat pengetahuan dan keterampilan petani masih rendah, terbatasnya sarana dan prasarana pengolahan serta modal usaha yang relatif kecil.

Sehingga penelitian ini penting untuk dilaksanakan, karena bermanfaat dalam mengembangkan perumusan strategi kebijakan terkait aspek-aspek (komponen) potensi wilayah yang berpengaruh untuk pengembangan komoditas perkebunan. Harapannya agar Pemerintah Daerah dapat memberikan fasilitas untuk pengembangan agroindustri perkebunan unggulan. Fasilitas tersebut dapat berupa pembinaan yang intensif seperti kewirausahaan dan penyuluhan. Disamping itu perlu mendorong kemitraan antara pengusaha skala kecil dan menengah dengan pengusaha skala besar terutama dalam hal pemasaran produk dan pembinaan mutu dalam upaya menambah nilai tambah produksi. 


\section{Tujuan Penelitian}

1. Untuk menganalisis komoditas unggulan sub sektor perkebunan di Kabupaten Bengkayang Provinsi Kalimantan Barat.

2. Untuk menganalisis struktur dan laju pertumbuhan produksi komoditas sub sektor perkebunan di Kabupaten Bengkayang Provinsi Kalimantan Barat tahun 2005-2012?.

\section{METODE PENELITIAN}

Metode dasar yang digunakan dalam penelitian ini adalah metode deskriptif analitis. Yaitu. yang digunakan untuk menemukan fakta dengan interpretasi yang tepat berdasarkan data-data, bersifat eksploratif dan bertujuan untuk mencari fenomena untuk penelitian selanjutnya. Lokasi penelitian ditentukan dengan sengaja (purposive) dengan alasan yaitu Kabupaten Bengkayang yang memiliki komoditi tanaman perkebunan strategis yang cukup beragam.

\section{Metode Analisis Data}

\section{a. Identifikasi Subsektor Basis}

\section{1) Analisis Location Quotient (LQ)}

Analisis LQ merupakan salah satu pendekatan tidak langsung yang digunakan untuk mengetahui apakah suatu sektor atau komoditas merupakan sektor basis atau non-basis. LQ adalah suatu metode untuk menghitung perbandingan relatif sumbangan nilai tambah sebuah sektor di suatu daerah (Kabupaten/Kota) terhadap sumbangan nilai tambah sektor yang bersangkutan dalam skala provinsi atau nasional. Dengan kata lain, LQ dapat menghitung perbandingan antara share output sektor $i$ di kota/kabupaten dan share output sektor $i$ di provinsi.

Nilai LQ akan memberikan indikasi kemampuan suatu daerah dalam menghasilkan suatu komoditas, apakah mempunyai potensi untuk mensupply daerah lain, mendatangkan dari daerah lain, atau dalam keadaan seimbang. Teknik LQ relevan juga digunakan sebagai metode untuk menentukan komoditas unggulan khususnya dari sisi penawaran (produksi atau populasi) (Hendayana, 2003). Secara matematis formula LQ adalah sebagai berikut :

$$
L Q_{i}=\frac{Y_{i j} / Y_{j}}{Y_{i} / Y}
$$

Keterangan :

$\mathrm{Y}_{\mathrm{ij}}$ : Nilai produksi komoditi perkebunan di Kabupaten Bengkayang.

$\mathrm{Y}_{\mathrm{j}}$ : Total nilai produksi komoditi perkebunan Kabupaten Bengkayang.

$Y_{i}$ : Nilai produksi komoditi perkebunan di Provinsi Kalimantan Barat

Y : Total nilai produksi komoditi perkebunan Kalimantan Barat

Dari hasil perhitungan LQ dapat diketahui bahwa :

1. Jika $L Q>1$, berarti sektor/subsektor tersebut merupakan sektor basis atau sektor unggul di Provinsi Kalimantan Barat.

2. Jika $L Q<1$, berarti sektor/subsektor tersebut merupakan sektor non basis atau sektor non unggul. 


\section{2) Analisis Dynamic Location Quotient (DLQ)}

Dengan menggunakan notasi gij dan Gi akan digunakan untuk menyatakan laju pertumbuhan sektor (i) di daerah (j) dan di daerah himpunannya, sedangkan notasi gj dan G menunjukkan rata-rata laju pertumbuhan ekonomi daerah (j) dan daerah himpunan. Dengan notasi demikian, maka persamaannya dapat dirumuskan (Yuwono dalam Widodo, 2006) sebagai berikut :

$$
D L Q_{i j}=\left[\frac{\left(1+g_{i j}\right) /\left(1+g_{j}\right)}{\left(1+G_{i}\right) /(1+G)}\right]^{i}
$$

Keterangan :

DLQ : Indeks Dynamic Location Quotient

$g_{i j}$ : Rata-rata pertumbuhan produksi komoditi perkebunan di Kabupaten Bengkayang

$g_{i}$ : Rata-rata pertumbuhan total produksi komoditi perkebunan di Kabupaten Bengkayang

$\mathrm{G}_{\mathrm{i}}$ : Rata-rata laju pertumbuhan produksi komoditi perkebunan di Provinsi Kalimantan Barat

G : Rata-rata pertumbuhan total produksi komoditi perkebunan di Provinsi Kalimantan Barat

t : Kurun waktu analisis

Kriteria :

1. DLQ $>1$, sektor/subsektor pertanian masih dapat diharapkan untuk menjadi basis di masa yang akan datang.

2. $\mathrm{DLQ}<1$, sektor/subsektor pertanian tidak dapat diharapkan untuk menjadi basis di masa yang akan datang.

\section{3) Gabungan LQ dan DLQ}

Mengkombinasikan nilai dari LQ dan DLQ dengan kriteria sebagai berikut (Suryatno, 2000 dalam Ariyani 2005) :

1. $L Q>1$ dan $D L Q>1$, maka sektor pertanian belum mengalami reposisi artinya sektor/subsektor pertanian yang menjadi basis pada saat itu juga masih menjadi basis dimasa mendatang.

2. $\mathrm{LQ}>1$ dan $\mathrm{DLQ}<1$, maka sektor/subsektor pertanian telah mengalami reposisi dan tidak bisa diharapkan untuk menjadi basis dimasa yang akan datang.

3. $L Q<1$ dan DLQ > 1, maka sektor/subsektor pertanian telah mengalami reposisi dari sektor nonbasis menjadi sektor basis.

4. $L Q<1$ dan $D L Q<1$, maka sektor/subsektor pertanian belum mengalami reposisi dan tetap menjadi sektor nonbasis.

\section{4) Analisis Shift-Share}

Analisis Shift Share adalah analisis yang bertujuan untuk menentukan kinerja atau produktivitas kerja perekonomian daerah dengan membandingkannya dengan daerah yang lebih besar (regional atau nasional). 
Teknik analisis shift share ini membagi pertumbuhan sebagai perubahan (D) suatu variabel wilayah, seperti tenaga kerja, nilai tambah, pendapatan atau output, selama kurun waktu tertentu menjadi pengaruhpengaruh : pertumbuhan nasional $(\mathrm{N})$, industri mix/bauran industri (M), dan keunggulan kompetitif ( $\mathrm{C}$ ).

Menurut Prasetyo Soepomo (1993) bentuk umum persamaan dari analisis shift share dan komponen-komponennya adalah :

\section{$\mathbf{D} \mathbf{i j}=\mathbf{N} \mathbf{i j}+\mathbf{M} \mathbf{i j}+\mathbf{C} \mathbf{i j}$}

$$
\begin{aligned}
& \text { Keterangan : } \\
& \mathrm{i}=\text { = Sektor-sektor ekonomi yang diteliti } \\
& \mathrm{j} \quad=\text { Variabel wilayah yang diteliti Kabupaten Bengkayang } \\
& \mathrm{n} \quad=\text { Variabel wilayah Provinsi Kalimantan Barat } \\
& \mathrm{D} \text { ij = Perubahan sektor } \mathrm{i} \text { di daerah } \mathrm{j} \text { (Kabupaten Bengkayang) } \\
& \mathrm{N} \text { ij = Pertumbuhan nasional sektor } \mathrm{i} \text { di daerah } \mathrm{j} \text { (Kabupaten Bengkayang) } \\
& \mathrm{M} \text { ij = Bauran industri sektor } \mathrm{i} \text { di daerah } \mathrm{j} \text { (Kabupaten Bengkayang) } \\
& \mathrm{C} \text { ij = Keunggulan kompetitif sektor } \mathrm{i} \text { di daerah } \mathrm{j} \text { (Kabupaten Bengkayang) }
\end{aligned}
$$

Dalam penelitian ini variabel yang digunakan adalah hasil produksi komoditas perkebunan yang dinotasikan sebagai (y). maka :

$$
\mathrm{Dij}=\mathrm{y}^{*} \mathrm{ij}-\mathrm{y} \text { ij Nij =y ij .r } n \text { Mij =y ij ( } r \text { in }-r \text { n) Cij =y ij ( } \mathrm{ij}-r \text { in) }
$$

Keterangan :

y ij = Produksi komoditi perkebunan di daerah j (Kabupaten Bengkayang)

$\mathrm{y} \mathrm{ij}=$ Produksi komoditi perkebunan di daerah $\mathrm{j}$ akhir tahun analisis (Kabupaten Bengkayang)

r ij = Laju pertumbuhan komoditi perkebunan di daerah j (Kabupaten Bengkayang)

$r$ in = Laju pertumbuhan komoditi perkebunan di daerah $n$ (Provinsi Kalimantan Barat)

$r n=$ Rata-rata Laju pertumbuhan komoditi perkebunan di daerah $n$ (indonesia)

\section{5) Analisis Shift Share Modifikasi Esteban - Marquillas.}

Analisis ini menggunakan rumus dari hasil modifikasi Shift Share Klasik sebagai berikut (Soepono, 1993 : 47) dalam (Zam, 2002) :

$$
\begin{aligned}
& D_{i j}=N_{i j}+M_{i j}+C_{i j}^{\prime}+A_{i j} \\
& C_{i j}^{\prime}=E_{i j}^{\prime}\left(r_{i j}-r_{i n}\right) \\
& A_{i j}=\left(E_{i j}-E_{i j}^{\prime}\right)\left(r_{i j}-r_{i n}\right)
\end{aligned}
$$

$$
E_{i j}^{\prime}=E_{j} \frac{E_{i n}}{E_{n}}
$$

Keterangan :

$\mathrm{C}_{\mathrm{ij}}^{\prime}=$ ukuran keunggulan atau ketidakunggulan kompetitif di sektor $\mathrm{i}$ wilayah $\mathrm{j}$

$\mathrm{E}_{\mathrm{ij}}^{\prime}=$ homothetic PDRB Kabupaten Kapuas Hulu yang diharapkan, merupakan pendapatan atau nilai tambah yang dicapai sektor $\mathrm{i}$ di wilayah $\mathrm{j}$. 

$A_{i j}=$ sebagai bagian dari pengaruh (keunggulan) kompetitif klasik yang juga menunjukkan tingkat spesialisasi di sektor i wilayah j.
$E_{j}=$ total PDRB Kabupaten Kapuas Hulu pada tahun awal.

\section{HASIL DAN PEMBAHASAN}

\section{Perkembangan Produksi dan Luas Tanam Komoditas Perkebunan di Kabupaten Bengkayang}

Adapun perkembangan Produksi dan Luas Tanam Komoditas Sub Sektor Perkebunan di Kabupaten Bengkayang Provinsi Kalimantan Barat dalam 3 tahun terakhir dapat dilihat pada gambar grafik berikut :
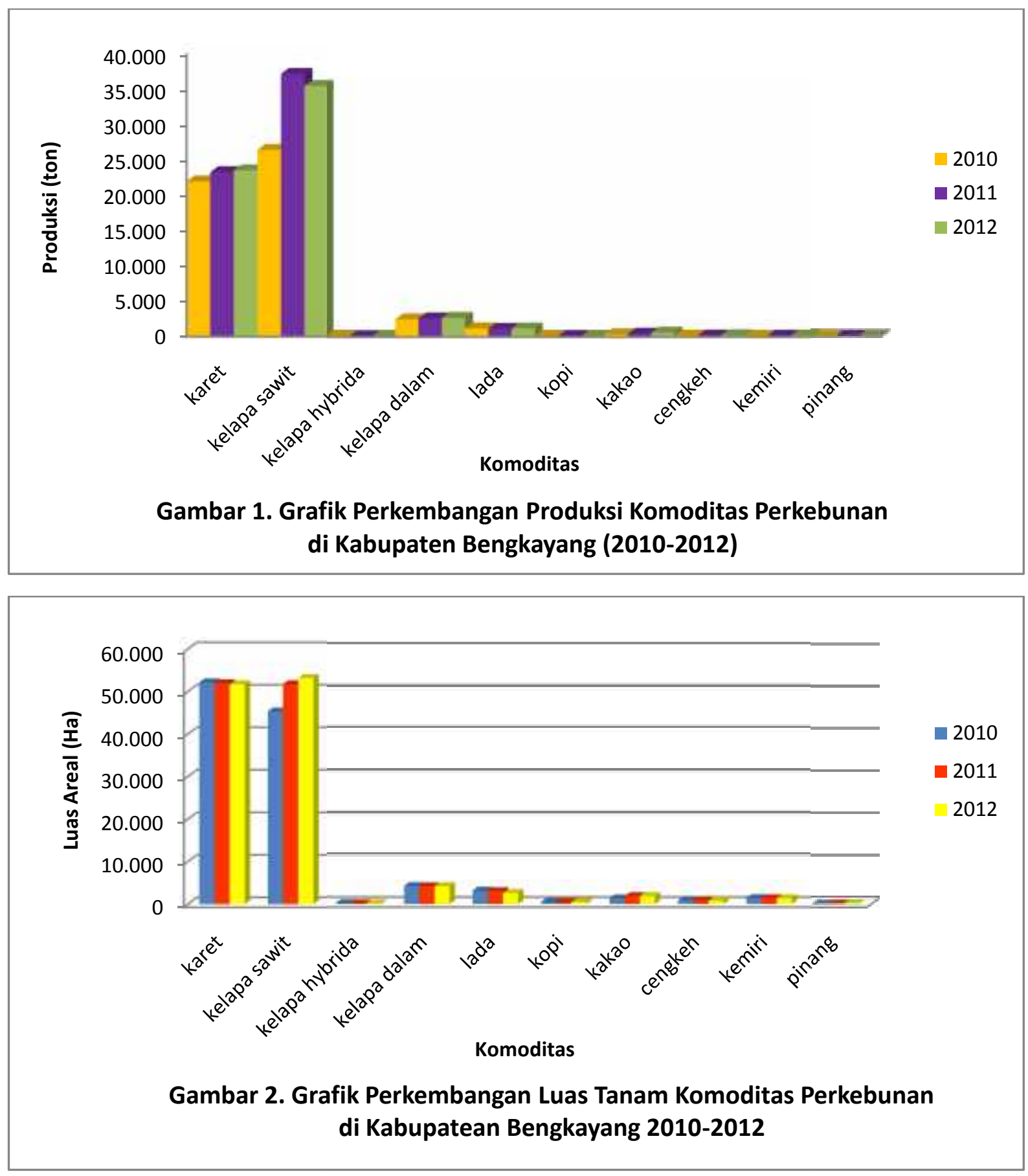


\section{Analisis identifikasi Komoditas Unggulan Sektor Perkebunan di Kabupaten Bengkayang}

\section{Analisis Location Quotient (LQ)}

Hasil analisis Location Quotient (LQ) terhadap PDRB Kabupaten Bengkayang selama periode penelitian (2005-2012) dapat dilihat pada Tabel 1 yang menyajikan hasil analisis LQ sektor perekonomian.

Tabel 1. Hasil Analisis Location Quotient (LQ) Komoditas Sub Sektor Perkebunan Kabupaten Bengkayang Tahun 2005-2012

\begin{tabular}{lcccccccccc}
\hline Komoditi & $\mathbf{2 0 0 5}$ & $\mathbf{2 0 0 6}$ & $\mathbf{2 0 0 7}$ & $\mathbf{2 0 0 8}$ & $\mathbf{2 0 0 9}$ & $\mathbf{2 0 1 0}$ & $\mathbf{2 0 1 1}$ & $\mathbf{2 0 1 2}$ & Rata-rata & Kriteria \\
\hline karet & 2,12 & 2,35 & 2,38 & 2,29 & 2,27 & 2,12 & 1,87 & 2,00 & 2,17 & $\mathrm{~B}$ \\
kelapa sawit & 0,61 & 0,58 & 0,58 & 0,61 & 0,63 & 0,68 & 0,77 & 0,74 & 0,65 & $\mathrm{NB}$ \\
kelapa hybrida & 0,22 & 0,27 & 0,27 & 0,23 & 0,26 & 0,28 & 0,27 & 0,32 & 0,26 & $\mathrm{NB}$ \\
kelapa dalam & 1,11 & 1,18 & 1,04 & 1,03 & 0,83 & 0,80 & 0,71 & 0,80 & 0,94 & $\mathrm{NB}$ \\
lada & 7,40 & 7,94 & 7,68 & 6,97 & 6,45 & 6,45 & 5,54 & 7,39 & 6,98 & $\mathrm{~B}$ \\
kopi & 0,73 & 0,73 & 0,79 & 0,70 & 0,71 & 0,73 & 0,60 & 0,71 & 0,71 & $\mathrm{NB}$ \\
kakao & 2,19 & 3,02 & 4,06 & 4,04 & 3,97 & 3,58 & 3,53 & 4,63 & 3,63 & $\mathrm{~B}$ \\
cengkeh & 15,53 & 16,55 & 19,86 & 20,54 & 20,49 & 22,14 & 19,25 & 21,51 & 19,48 & $\mathrm{~B}$ \\
kemiri & 14,48 & 16,64 & 17,87 & 16,92 & 17,01 & 18,51 & 14,99 & 17,03 & 16,68 & $\mathrm{~B}$ \\
Pinang & 0,94 & 0,33 & 0,19 & 0,14 & 0,17 & 0,21 & 0,16 & 0,30 & 0,30 & $\mathrm{NB}$ \\
\hline
\end{tabular}

Sumber : Data sekunder diolah (2013)

Keterangan : $\mathrm{B}=$ Basis (unggulan), $\mathrm{NB}=$ Non Basis (non unggulan)

Komoditas unggulan sub sektor perkebunan di Kabupaten Bengkayang Kalimantan Barat di dalam penelitian ini terdiri dari 10 komoditas unggulan yang banyak paling banyak diusahakan/dihasilkan. Data yang digunakan untuk 10 komoditas di atas adalah data produksi yang telah mempertimbangkan aspek agronomis dan sosial ekonomi dari tahun 2005-2012. Ke-10 komoditas tersebut adalah Karet, Kelapa Sawit, Kelapa Hiybrida, Kelapa Dalam, Lada, Kopi, Kakao, Cengkeh, Kemiri dan Pinang.

Berdasarkan hasil analisis LQ pada tabel 1 di atas menunjukkan bahwa komoditas unggulan sub sektor perkebunan di Kabupaten Bengkayang adalah Karet, Lada, Kakao, Cengkeh dan Kemiri dengan nilai LQ > 1. Sedangkan tanaman Kelapa Sawit, Kelapa Dalam, Kelapa Hybrida Kopi dan Pinang adalah komoditas non unggulan dengan nilai $L Q<$ 1.

\section{Analisis Dynamic Location Quotient (DLQ)}

Analisis DLQ digunakan untuk menentukan reposisi komoditas unggulan ke depan di daerah tertentu. Analisis ini penting digunakan untuk mengetahui apakah di masa yang akan datang komoditas tertentu dapat bertahan sebagai komoditas unggulan atau tidak dan sebaliknya apakah komoditas yang sebelumnya bukan unggulan dapat mengalami reposisi/berpotensi menjadi komoditas unggulan di masa yang akan datang.

Tafsiran atas nilai DLQ sebenarnya masih sama dengan LQ, kecuali perbandingan ini lebih menekankan pada laju pertumbuhan. Jika $D L Q=1$, berarti laju pertumbuhan komoditas i terhadap laju pertumbuhan total nilai produksi daerah sebanding dengan laju pertumbuhan komoditas tersebut terhadap total nilai produksi nasional. Jika DLQ $<1$, artinya proporsi laju pertumbuhan komoditas i terhadap laju pertumbuhan total nilai produksi daerah lebih rendah dibandingkan laju pertumbuhan komoditas tersebut terhadap total nilai produksi nasional. Kondisi demikian menyatakan bahwa selama kondisi komoditas masih tetap sebagaimana adanya, maka masa depan komoditas ini akan kalah bersaing dengan komoditas yang sama untuk memenuhi kebutuhan wilayahnya sendiri, artinya daerah tersebut. Memiliki kecenderungan untuk melakukan impor dari daerah lain. Dapat juga 
dikatakan bahwa wilayah tersebut tidak berspesialisasi pada komoditas tersebut. Hasil perhitungan DLQ dapat dilihat pada Tabel 2.

Tabel 2. Hasil Analisis Dynamic Location Quotient (DLQ) Sub Sektor Perkebunan Kabupaten Bengkayang Tahun 2005-2012

\begin{tabular}{lrrrrrrrrr}
\hline \multicolumn{1}{c}{ Komoditi } & \multicolumn{1}{c}{$\mathbf{2 0 0 6}$} & $\mathbf{2 0 0 7}$ & $\mathbf{2 0 0 8}$ & $\mathbf{2 0 0 9}$ & $\mathbf{2 0 1 0}$ & $\mathbf{2 0 1 1}$ & $\mathbf{2 0 1 2}$ & Rata-rata & Kriteria \\
\hline karet & $-10,22$ & 0,87 & 1,74 & 0,39 & 0,02 & 0,12 & $-0,63$ & $-1,10$ & NB \\
kelapa sawit & 0,02 & 0,68 & $-3,92$ & $-0,85$ & 0,29 & 0,30 & 0,49 & $-0,43$ & NB \\
kelapa hybrida & $-0,45$ & 0,42 & 5,57 & 0,16 & $-0,01$ & $-0,03$ & 1,38 & 1,01 & B \\
kelapa dalam & 0,29 & $-0,49$ & 7,02 & 4,55 & 0,04 & 0,23 & $-4,93$ & 1,00 & B \\
Lada & 0,33 & 0,47 & 2,71 & $-3,28$ & 0,06 & 0,03 & 0,50 & 0,12 & NB \\
Kopi & 1,20 & $-1,09$ & 3,35 & 2,29 & 0,07 & 0,03 & 0,41 & 0,89 & NB \\
kakao & 1,61 & $-5,93$ & $-0,39$ & $-0,32$ & $-0,12$ & 0,12 & $-4,29$ & $-1,33$ & NB \\
cengkeh & 0,33 & $-0,30$ & $-0,05$ & $-0,23$ & $-0,02$ & 6,79 & $-1,62$ & 0,70 & NB \\
kemiri & $-0,23$ & $-0,17$ & 0,70 & 0,15 & 0,56 & 0,03 & $-2,05$ & $-0,14$ & NB \\
Pinang & 0,03 & $-0,19$ & 11,56 & $-8,08$ & 1,09 & $-0,31$ & 0,55 & 0,67 & NB \\
\hline
\end{tabular}

Sumber : Data sekunder diolah (2013)

Keterangan : $\mathrm{B}=$ Basis (unggulan), NB = Non Basis (non unggulan)

Tabel di atas menunjukkan bahwa komoditas kelapa hybrida dan kelapa dalam merupakan komoditas unggulan sub sektor perkebunan yang dapat diharapkan pada masa yang akan datang (DLQ lebih dari satu). Sebaliknya, Karet, Kelapa Sawit, Lada, Kopi, Kakao, Cengkeh dan Kemiri memiliki nilai DLQ kurang dari satu, artinya merupakan sektor yang tidak dapat diharapkan menjadi unggulan pada masa yang akan datang.

\section{Gabungan LQ dan DLQ}

Terjadinya reposisi suatu komoditas di masa yang akan datang dapat diketahui dengan cara menggabungkan nilai LQ dan DLQ. Data yang menunjukkan bila nilai LQ adalah non unggulan sementara pada nilai DLQ unggulan, berarti bahwa komoditas tersebut mengalami reposisi untuk menjadi unggulan di masa yang akan datang. Adapun data yang menunjukkan nilai LQ dan DLQ pada komoditas sub sektor perkebunan di Kabupaten Bengkayang Provinsi Kalimantan barat dapat dilihat pada tabel berikut.

Tabel 3. Perbandingan Nilai LQ dan DLQ Sektor Perekonomian Kabupaten Bengkayang Tahun 2005-2012

\begin{tabular}{lccc}
\hline \multicolumn{1}{c}{ Komoditas } & Nilai LQ & Nilai DLQ & Kriteria \\
\hline karet & 2,17 & $-1,10$ & reposisi non unggulan \\
kelapa sawit & 0,65 & $-0,43$ & non unggulan \\
kelapa hybrida & 0,26 & 1,01 & reposisi unggulan \\
kelapa dalam & 0,94 & 1,00 & reposisi unggulan \\
lada & 6,98 & 0,12 & reposisi non unggulan \\
kopi & 0,71 & 0,89 & non unggulan \\
kakao & 3,63 & $-1,33$ & reposisi non unggulan \\
cengkeh & 19,48 & 0,70 & reposisi non unggulan \\
kemiri & 16,68 & $-0,14$ & reposisi non unggulan \\
Pinang & 0,30 & 0,67 & non unggulan \\
\hline
\end{tabular}

Sumber : Data sekunder diolah (2013)

Tabel di atas menunjukkan bahwa ada 2 komoditas yang mengalami reposisi dari non unggulan menjadi komoditas unggulan di masa yang akan datang, yaitu komoditas Kelapa Hybrida dan Kelapa dalam. Adapun komoditas yang mengalami reposisi dari unggulan menjadi non unggulan di masa yang akan datang adalah komoditas Karet, Lada, 
Kakao, Cengkeh dan Kemiri. Sedangkan komoditas yang akan tetap menjadi non unggulan di masa yang akan datang adalah Kelapa Sawit, Kopi dan Pinang.

Hasil analisis gabungan LQ dan DLQ menunjukkan bahwa bila dibandingkan dengan laju hasil produksi komoditas perkebunan serupa yang dihasilkan oleh Kabupaten lain di Provinsi Kalimantan Barat menunjukkan bahwa komoditas Kelapa dalam dan Kelapa Hybrida di masa yang akan datang diharapkan memiliki potensi untuk dikembangkan atau menjadi komoditas unggulan di Kabupaten Bengkayang. Walaupun Karet dan Kelapa Sawit merupakan komoditas tanaman perkebunan utama di Kabupaten Bengkayang dengan luas tanam dan produksi yang paling besar dibandingkan dengan komoditas lainnya yang diusahakan, jika dilihat atau dibandingkan secara absolut dengan wilayah di atasnya (provinsi Kalimantan Barat) hasil produksi dan laju pertumbuhan tanaman Kelapa Sawit dan Karet masih kalah jauh dibandingkan dengan Kabupaten lain yang ada di provinsi Kalimantan Barat. Misalnya tahun 2012 produksi dan luas tanam komoditas kelapa sawit tertinggi berada di Kabupaten Ketapang dan Kabupaten Sintang dengan hasil produksi dan luas tanam masing-masing 266.350 ton, 278.525 hektar dan 116,669 ton, 103,963 hektar. Bandingkan dengan hasil produksi Kelapa Sawit di Kabupaten Bengkayang yang hanya 35,473 ton dengan luas areal tanam 53.213 hektar (Dinas Perkebunan Provinsi Kalimantan Barat, 2013). Komoditas yang tadinya menjadi komoditas unggulan seperti tanaman Lada dengan spesies Bengkayang Peppers, berdasarkan hasil analisis gabungan LQ dan DLQ menunjukkan bahwa komoditas ini tidak bisa lagi diharapkan menjadi basis (unggulan) di masa yang akan datang. Hal ini sejalan dengan hasil produksi dan luas areal tanam yang cenderung menurun dari tahun ke tahun ( data 2006-2012) untuk komoditas ini. Misalnya tahun 2011 luas tanam untuk tanaman lada adalah 2.985 ha dan hasil produksinya 1.182 ton, tahun 2012 luas tanam dan produksinya turun menjad 2.551 ha dengan hasil 1.139 ton.

\section{Analisis Struktur dan Laju Pertumbuhan}

\section{Analisis Shift Share Klasik}

Analisis Shift Share Klasik menjelaskan pengaruh komoditas sub sektor perkebunan pada wilayah yang lebih tinggi (Provinsi Kalimantan Barat) terhadap komoditas sub sektor perkebunan daerah (Kabupaten Bengkayang). Pengaruh komponen pertumbuhan produksi (dalam ton) di Provinsi Kalimantan Barat $\left(\mathrm{N}_{\mathrm{ij}}\right)$ menunjukkan seberapa besar pertumbuhan produksi komoditas tanaman perkebunan di provinsi berpengaruh (positif atau negatif) terhadap pertumbuhan produksi komoditas tanaman perkebunan di Kabupaten Bengkayang. Pengaruh bauran industri provinsi Kalimantan Barat $\left(\mathrm{M}_{\mathrm{ij}}\right)$, menunjukkan seberapa besar pengaruh laju pertumbuhan produksi komoditas perkebunan di provinsi Kalimantan Barat sektor i $\left(r_{\text {in }}\right)$ dan total laju pertumbuhan produksi komoditas perkebunan di provinsi Kalimantan Barat $\left(r_{n}\right)$ terhadap pertumbuhan produksi sektor i di Kabupaten Bengkayang. Komponen keunggulan kompetitif $\left(\mathrm{C}_{\mathrm{ij}}\right)$, yaitu pengaruh laju pertumbuhan produksi komoditas perkebunan sektor $\mathrm{i}\left(r_{\mathrm{ij}}\right)$ di Kabupaten Bengkayang dengan total laju pertumbuhan produksi komoditas perkebunan sektor i provinsi Kalimantan Barat $\left(r_{\text {im }}\right)$. Hasil analisis shift share klasik dapat dilihat pada tabel berikut. 
Tabel 4. Perubahan Struktural dan Komponen yang Mempengaruhi Komoditas Unggulan Sub Sektor Perkebunan Kabupaten Bengkayang Tahun 2005 - 2012

\begin{tabular}{lrrrr}
\hline \multicolumn{1}{c}{ Komoditi } & \multicolumn{1}{c}{$\mathbf{N}_{\mathrm{ij}}$} & \multicolumn{1}{c}{$\mathbf{M}_{\mathrm{ij}}$} & \multicolumn{1}{c}{$\mathbf{C}_{\mathrm{ij}}$} & \multicolumn{1}{c}{$\mathbf{D}_{\mathbf{i j}}$} \\
\hline karet & $7.360,70$ & $-4.019,86$ & $-1.931,84$ & $1.409,00$ \\
kelapa sawit & $7.082,18$ & $1.846,03$ & $5.261,80$ & $14.190,00$ \\
kelapa hybrida & 21,96 & $-48,01$ & 18,05 & $-8,00$ \\
kelapa dalam & $1.150,69$ & $-800,77$ & $-1.125,92$ & $-776,00$ \\
lada & 478,18 & $-710,08$ & $-23,10$ & $-255,00$ \\
kopi & 50,25 & $-70,23$ & $-6,02$ & $-26,00$ \\
kakao & 66,55 & 21,92 & 309,53 & 398,00 \\
cengkeh & 54,91 & $-50,58$ & 60,68 & 65,00 \\
kemiri & 44,26 & $-7,31$ & 26,06 & 63,00 \\
pinang & 2,66 & 17,60 & $-19,26$ & 1,00 \\
\hline \multicolumn{1}{c}{ jumlah } & $\mathbf{1 6 . 3 1 2 , 3 3}$ & $\mathbf{- 3 . 8 2 1 , 2 9}$ & $\mathbf{2 . 5 6 9 , 9 6}$ & $\mathbf{1 5 . 0 6 1 , 0 0}$ \\
\hline
\end{tabular}

Sumber : Data sekunder diolah (2013)

Tabel 4 di atas menunjukkan bahwa selama periode penelitian (2005 - 2012), komoditas perkebunan yang mengalami peningkatan pertumbuhan riil di Kabupaten Bengkayang adalah Karet, Kelapa Sawit, Kakao, Cengkeh, Kemiri dan Pinang.. Peningkatan terbesar terjadi pada komoditas Kelapa Sawit dan Karet dengan nilai pertumbuhan produksi masing-masing 14.190 ton dan 1.409 ton. Adapun komoditas yang mengalami penurunan produksi riil yaitu Kelapa Dalam, Lada, Kopi dan Kelapa Hybrida.

Kenaikan dan penurunan pertumbuhan produksi komoditas sub sektor perkebunan di Kabupaten Bengkayang dipengaruhi oleh beberapa faktor, yaitu diantaranya pengaruh pertumbuhan produksi komoditas perkebunan Provinsi Kalimantan Barat $\left(\mathrm{N}_{\mathrm{ij}}\right)$. Pertumbuhan produksi karet di Kabupaten Bengkayang dipengaruhi oleh pertumbuhan komoditas Karet Provinsi Kalimantan Barat selama periode 2005 - 2012 yaitu sebesar 7.360,70 ton. Pengaruh pertumbuhan Kelapa Sawit di provinsi Kalimantan Barat yaitu sebesar Rp. 7.082,18 ton , Kelapa Hybrida sebesar 21,96 ton, Kelapa Dalam sebesar 1.150,69 ton , Lada sebesar 478,18 ton, Kopi 50,25 ton, Kakao 66,55.ton, Cengkeh 54,91 ton, Kemiri 44,26 ton, Pinang 2,66 ton

Pengaruh komponen bauran industri $\left(\mathrm{M}_{\mathrm{ij}}\right)$ yang bernilai positif menunjukkan bahwa laju pertumbuhan produksi komoditas sub sektor perkebunan di Kabupaten Bengkayang mengalami peningkatan. Komoditas yang mengalami pertumbuhan produksi adalah Kelapa Sawit, Kako dan Pinang. Kelapa Sawit memiliki peningkatan pertumbuhan produksi tertinggi yaitu sebesar 1.846,03 ton. Komoditas perkebunan yang mengalami penurunan laju pertumbuhan produksi paling besar adalah Karet dengan nilai - 4.019, 86 ton.

Dilihat dari nilai $C_{i j}$ (komponen keunggulan kompetitif), diketahui bahwa komoditas yang memiliki keunggulan kompetitif adalah Kelapa Sawit. Kelapa Hybrida, Kakao, Cengkeh dan Kemiri. Kelapa Sawit merupakan komoditas dengan tingkat keunggulan kompetitif paling tinggi dibandingkan komoditas lainnya yaitu sebesar $5.261,80$ ton. Komoditas yang tidak memiliki keunggulan kompetitif adalah Karet, Kelapa Dalam, Lada, Kopi, dan Pinang. Karet mengalami penurunan competitiveness terbesar yaitu sebesar 1.931,84 ton.

\section{Analisis Shift Share Modifikasi Esteban Marquillas (E - M)}

Analisis Shift Share Modifikasi Esteban Marquillas ( E- M) memiliki perbedaan analisis ini dengan analisis Shift Share Klasik, yaitu pada komponen keunggulan kompetitif $\left(C_{i j}\right)$, sedangkan untuk $D_{i j}$ dan $M_{i j}$ serta $N_{i j}$ adalah konstan/tetap. Komponen $C_{i j}$ pada analisis shift share E-M mengandung unsur baru yaitu homothetic atau nilai tambah yang dicapai suatu komoditas di suatu wilayah. Analisis ini membagi nilai $\mathrm{C}_{\mathrm{ij}}$ menjadi dua komponen lain yaitu komponen keunggulan kompetitif $\left(\mathrm{C}_{\mathrm{ij}}^{\prime}\right)$ dan komponen pengaruh keunggulan alokasi $\left(A_{i j}\right)$. 
Tabel 5. Hasil Analisis Shift Share Modifikasi Esteban - Marquillas (E-M) terhadap Produksi Komoditas Sub Sektor Perkebunan Kabupaten Bengkayang Tahun 2005 - 2012 (dalam ton)

\begin{tabular}{lccccc}
\hline \multicolumn{1}{c}{ Komoditas } & $\mathbf{N}_{\mathrm{ij}}$ & $\mathbf{M}_{\mathrm{ij}}$ & $\mathbf{C}_{\mathrm{ij}}$ & $\mathbf{A}_{\mathrm{ij}}$ & $\mathbf{D}_{\mathrm{ij}}$ \\
\hline karet & $7.360,70$ & $(4.019,86)$ & $(911,36)$ & $(1.020,48)$ & $1.409,00$ \\
kelapa sawit & $7.082,18$ & $1.846,03$ & $8.565,97$ & $(3.304,17)$ & $14.190,00$ \\
kelapa hybrida & 21,96 & $(48,01)$ & 83,05 & $(65,00)$ & $(8,00)$ \\
kelapa dalam & $1.150,69$ & $(800,77)$ & $(1.014,06)$ & $(111,86)$ & $(776,00)$ \\
lada & 478,18 & $(710,08)$ & $(3,12)$ & $(19,98)$ & $(255,00)$ \\
kopi & 50,25 & $(70,23)$ & $(8,20)$ & 2,18 & $(26,00)$ \\
kakao & 66,55 & 21,92 & 141,36 & 168,17 & 398,00 \\
cengkeh & 54,91 & $(50,58)$ & 3,91 & 56,77 & 65,00 \\
kemiri & 44,26 & $(7,31)$ & 1,80 & 24,26 & 63,00 \\
pinang & 2,66 & 17,60 & $(20,55)$ & 1,29 & 1,00 \\
\hline \multicolumn{1}{c}{ jumlah } & $\mathbf{1 6 . 3 1 2 , 3 3}$ & $\mathbf{( 3 . 8 2 1 , 2 9 )}$ & $\mathbf{6 . 8 3 8 , 7 8}$ & $\mathbf{( 4 . 2 6 8 , 8 2 )}$ & $\mathbf{1 5 . 0 6 1 , 0 0}$ \\
\hline
\end{tabular}

Sumber : Data sekunder diolah (2013)

Komoditas perkebunan yang memiliki keunggulan kompetitif dengan peningkatan pertumbuhan produksi adalah Kelapa Sawit, Kelapa Hybrida, Kakao, Cengkeh dan Kemiri . Kelapa Sawit memiliki keunggulan kompetitif tertinggi yaitu sebesar 8.565,97 ton. komoditas yang tidak mengalami keunggulan kompetitif dengan pengurangan pertumbuhan laju produksi yaitu Karet, Kelapa Dalam, Lada, Kopi, dan Pinang. Hasil analisis komponen keunggulan kompetitif $\left(\mathrm{C}_{\mathrm{ij}}^{\prime}\right)$ ini identik dengan komponen differential shift analisis shift share klasik.

Komoditas sub sektor perkebunan yang memiliki keunggulan alokasi dan dapat meningkatkan pertumbuhan produksi tanaman perkebunan di Kabupaten Bengkayang adalah Kopi, Kakao, Cengkeh, Kemiri dan Pinang. Komoditas Kakao memiliki Keunggulan alokasi paling tinggi dalam meningkatkan produksi perkebunan di Kabupaten Bengkayang yaitu sebesar 168,17 ton. Komoditas Kakao ini juga merupakan komoditas yang memiliki keunggulan kompetitif sekaligus keunggulan alokasi dengan nilai positif paling tinggi.

\section{PENUTUP}

\section{Simpulan}

1. Analisis LQ menunjukkan bahwa komoditas sub sektor perkebunan yang menjadi unggulan/basis di Kabupaten Bengkayang adalah, Lada, Kakao, Cengkeh dan Kemiri.

2. Analisis DLQ menunjukkan bahwa sub sektor perkebunan yang menjadi unggulan/basis di Kabupaten Bengkayang adalah Kelapa Dalam dan Kelapa Hybrida

3. Analisis gabungan LQ dan DLQ menunjukkan bahwa ada 2 komoditas yang mengalami reposisi dari non unggulan menjadi komoditas unggulan di masa yang akan datang, yaitu komoditas Kelapa Hybrida dan Kelapa dalam. Adapun komoditas yang mengalami reposisi dari unggulan menjadi non unggulan di masa yang akan datang adalah komoditas Karet, Lada, Kakao, Cengkeh dan Kemiri. Sedangkan komoditas yang akan tetap menjadi non unggulan di masa yang akan datang adalah Kelapa Sawit, Kopi dan Pinang.

4. Analisis Shift Share Klasik menunjukkan bahwa selama periode penelitian (2005 2012), komoditas perkebunan yang mengalami peningkatan pertumbuhan riil di Kabupaten Bengkayang adalah Karet, Kelapa Sawit, Kakao, Cengkeh, Kemiri dan Pinang. Peningkatan terbesar terjadi pada komoditas Kelapa Sawit dan Karet dengan nilai pertumbuhan produksi masing-masing 14.190 ton dan 1.409 ton. 
5. Analisis Shift Share Modifikasi Esteban - Marquillas menunjukkan bahwa komoditas perkebunan yang memiliki keunggulan kompetitif dengan peningkatan pertumbuhan produksi adalah Kelapa Sawit, Kelapa Hybrida, Kakao, Cengkeh dan Kemiri. Kelapa Sawit memiliki keunggulan kompetitif tertinggi yaitu sebesar 8.565,97 ton.. Komoditas sub sektor perkebunan yang memiliki keunggulan alokasi dan dapat meningkatkan pertumbuhan produksi tanaman perkebunan di Kabupaten Bengkayang adalah Kopi, Kakao, Cengkeh, Kemiri dan Pinang. Komoditas Kakao memiliki Keunggulan alokasi paling tinggi dalam meningkatkan produksi perkebunan di Kabupaten Bengkayang yaitu sebesar 168,17 ton. Komoditas Kakao ini juga merupakan komoditas yang memiliki keunggulan kompetitif sekaligus keunggulan alokasi dengan nilai positif paling tinggi.

\section{Saran}

Berdasarkan hasil penelitian ini maka dapat dikemukakan beberapa saran yang dapat dipertimbangkan oleh pemerintah daerah dan instansi terkait sebagai berikut :

1. Pemerintah daerah Kabupaten Bengkayang dapat mempertimbangkan hasil penelitian ini dalam menentukan arah pengembangan sub sektor perkebunan di masa yang akan datang. Sebaiknya juga dilakukan penelitian lapangan yang lebih intensif untuk mendapatkan hasil kajian penelitian yang lebih tepat dan sempurna.

2. Pemerintah daerah Kabupaten Bengkayang hendaknya menyusun kebijakan yang dapat memberikan kemudahan dalam penyelenggaraan aktifitas - aktifitas yang berkaitan dengan pengembangan komoditas unggulan sektor perkebunan dari hulu (up stream) sampai ke hilir (down stream).

3. Komoditas tanaman perkebunan yang belum menjadi unggulan/basis hendaknya dipacu pertumbuhannya untuk menjadi sektor unggulan dalam rangka memperkuat sumbangan sub sektor perkebunan bagi pertumbuhan perekonomian Kabupaten Bengkayang. Hal ini dapat dilakukan dengan mengalokasikan dana pembangunan secara lebih proporsional, khususnya bagi perkembangan sektor perkebunan.

\section{DAFTAR PUSTAKA}

Anonim, 2011. PDB Perkebunan Secara Kumulatif Mengalami Peningkatan yang Signifikan Periode Tahun 2005 sampai dengan 2010. http://ditjenbun. deptan.go.id/index.php/component/content/article/36news/202.html.

Ariyani, A.H.M. 2005. Peran dan Identifikasi Komoditas Pertanian Unggulan di Kabupaten Wonogiri. Tesis Magister Manajemen Agribisnis. Universitas Gadjah Mada. Yogyakarta. Unpublished

Badan Pusat Statistik (BPS) Kalimantan Barat, 2011. Provinsi Kalimantan Barat dalam Angka Tahun 2011. Pontianak.

Dinas Perkebunan (Disbun) Provinsi Kalimantan Barat. Statistik Perkebunan Kalimantan Barat 2005-2012. Dinas Perkebunan Kalimantan Barat. Pontianak

Hendayana, R.. 2003. Aplikasi Metode Location Quotient (LQ) dalam Penentuan Komoditas Unggulan Nasional. Balai Pengkajian dan Pengembangan Teknologi Pertanian. Informatika Pertanian Vol 12 Desember 2003.

Sinaga, B.M dan Susilowati, S.R., 2007. Dampak Kebijakan Ekonomi di Sektor Agroindustri terhadap Distribusi Pendapatan Sektoral, Tenaga Kerja, dan Rumah Tangga di Indonesia. Jurnal Agro Ekonomi 25(1), 11-36.

Syam, H. dan Ma'arif, M.S., 2004. Kajian Perlunya Kebijakan Pengembangan Agroindustri Sebagai Leading Sector. Jurnal Agrimedia, 9(1), 32-39. 
Witjaksono J., Sulle A., dan Ruku S., 2008. Strategi Akselerasi Peningkatan Pendapatan Petani Jambu Mete di Sulawesi Tenggara. Jurnal SOCA (Socio-Economic of Agriculture and Agribusiness), 1, 1-18.

Widodo, T. 2006. Perencanaan Pembangunan : Aplikasi Komputer (Era Otonomi Daerah). UPP STIM YKPN. Yogyakarta.

Zam S, 2002. Penentuan Subsektor Unggulan Untuk Pembangunan Ekonomi Kota Pekanbaru. Tesis Magister Ekonomi Pembangunan. Universitas Gadjah Mada. Yogyakarta. Unpublished 